Економічні науки: збірник наукових праць Луцького національного технічного університету. - Серія "Регіональна економіка". - Випуск 15 (59). - Редкол.: відп. ред. д.е.н., професор Л.Л. Ковальська. - Луиьк: ІВВ Луиького НТУ, 2018. - 292 с.

УДК 338.48

Масечко I.B., аспірант

Луцький національний технічний університет

\title{
ПРОБЛЕМИ РОЗВИТКУ ЯКІСНОГО НАДАННЯ ТУРИСТИЧНИХ ПОСЛУГ В РЕГІОНІ
}

У статті розглянуто поняття якості послуг та можливі шляхи підвищення якості послуг для забезпечення ефективного розвитку туристичних послуг в регіоні і підвищення його конкурентоспроможності.

Ключові слова: якість, розвиток, туристичні послуги, сертифікація.

\section{Masechko I.V.}

\section{PROBLEMS OF DEVELOPMENT OF QUALITATIVE PROVISION OF TOURIST SERVICES IN THE REGION}

The article throws out the quality, which is the second main tool after the price, which forms the structure of the offer on the market. Considered the key factors contributing to improving the competitiveness of tourism products in the region due to the constant increase of its level. What caused the need to adapt the proposal to the needs of tourists.

The article explains and analyzes scientific approaches to the definition of the concept of quality. The interpretation of this economic category by modern domestic and foreign economists, the appropriateness of certification and standardization is reasonable for the provision of internal resources for the provision of tourist services in the regions of Ukraine. In today's conditions of tourism business, much attention should be paid to the implementation of a set of measures aimed at modernizing the provision of tourist services, developing effective standards for tourist services, and improving the work of all businesses in the tourism sector. In order to improve the organization of tourism activities in most countries of the world, special mechanisms of influence on economic entities that arise when implementing standardization procedures, certification of tourist services, licensing of tourism activities and depend on certain model of state regulation in the field of tourism are applied.

The article examines and analyzes scientific approaches to the definition of the concept of quality. The interpretation of this economic category by contemporary domestic and foreign economists is generalized, the feasibility of certification and standardization for the quality of providing tourist services in the regions of Ukraine is substantiated. The analysis of many components that affect quality, their selection is a significant problem in the study and assessment of the quality of tourist services. The scientific-theoretical and methodological basis of this 
Економічні науки: збірник наукових праць Луцького національного технічного університету. - Серія "Регіональна економіка". - Випуск 15 (59). - Редкол.: відп. ред. д.е.н., професор Л.Л. Ковальська. - Луцьк: ІВВ Луиького НТУ, 2018. - 292 с.

study were scientific works and publications of domestic and foreign scientists in the field of quality management of tourist services.

Kay words: quality, development, travel services, certification.

Масечко И.В.

\section{ПРОБЛЕМЫ РАЗВИТИЯ КАЧЕСТВЕННОГО ПРЕДОСТАВЛЕНИЯ ТУРИСТИЧЕСКИХ УСЛУГ В РЕГИОНЕ}

В статье рассмотрено понятие качества услуг и возможные пути повышения качества услуг для обеспечения эффективного развития туристических услуг в регионе и повышение его конкурентоспособности.

Ключевые слова: качество, развитие, туристические услуги, сертификация.

\section{Постановка проблеми у загальному вигляді i iї} зв'язок 3 важливими науковими та практичними завданнями. Сьогодні туризм у всьому світі $\epsilon$ однією 3 найбільш високоприбуткових галузей господарювання, яка в сучасних умовах постійно й динамічно розвивається, сприяючи вирішенню цілого комплексу життєво важливих соціальноекономічних проблем. Розвиток надання туристичних послуг в регіонах України знаходиться на етапі переходу до ринкової економіки й інтеграції зі світовим ринком. У зв'язку 3 цим, істотно підвищуються вимоги до рівня якості послуг, що надають суб’єкти даного ринку.

Проблема забезпечення конкурентоспроможності туристичних підприємств, тісно пов'язана 3 реалізацією досліджень у сфері управління якістю, забезпечення, підтримки і покращення рівня надання послуг. Ця галузь має стрижневу особливість, де забезпечення повноцінної послуги надається суміжними суб' єктами ринку. Спільна діяльність туристичних операторів, фірм 3 підприємствами безпосереднього обслуговування туристів, $€$ важливою умовою якісного виробництва туристичних послуг. 3 метою вдосконалення організаціі туристичної діяльності більшість країн світу застосовує спеціальні механізми впливу на суб'єктів 
Економічні науки: збірник наукових праць Луцького національного технічного університету. - Серія "Регіональна економіка". - Випуск 15 (59). - Редкол.: відп. ред. д.е.н., професор Л.Л. Ковальська. - Луцьк: ІВВ Луцького НТУ, 2018. - 292 с.

підприємництва, які виявляються у запроваджуванні процедури стандартизації, сертифікації туристичних послуг, ліцензування туристичної діяльності та залежать від певної моделі державного регулювання в галузі туризму.

Аналіз останніх досліджень, у яких започатковано вирішення проблеми. Значним внеском у дослідження теоретичних і практичних проблем якості туристичних послуг стали праці вчених Л. Дядечко, Л. Завідної, Н. Кудли, Н. Кузнєцової, В. Лук'янова, Л. Матвійчук, М. Мальської, Л. Нечаюк, В. Кифяка, П. Подлепіної, Т. Ткаченко, І. Школи, С. Цехли, Н. Чорненької та інших. Серед зарубіжних вчених подібна проблематика є також актуальною. Вона зустрічається в працях Д. Гарвіна, Дж. Джурана, А. Зоріна, В. Квартального, Дж. Харрингтона та інших.

Цілі статті. Основними напрямами дослідження $\epsilon$ визначення складових якості туристичних послуг та головних перешкод щодо забезпечення даної якості в регіоні.

Виклад основного матеріалу дослідження 3 повним обгрунтуванням отриманих наукових результатів. Якість $\epsilon$ одним 3 основних інструментів, який формує структуру пропозиції на ринку туристичних послуг регіонів. Вона $\epsilon$ ключовим чинником, що сприяє поліпшенню конкурентоспроможності туристичних регіонів внаслідок постійного підвищення ii рівня. Це зумовлено необхідністю пристосування пропозиції до потреб туристів.

Однією із основних проблем в розвитку туризму в Україні $\epsilon$ невідповідність вітчизняних стандартів світовим а також неповна захищеність вітчизняного споживача через недосконалу законодавчу базу. Для вирішення даних проблем необхідне вдосконалення процедур із планування, розроблення, гармонізації, прийняття і перегляду нормативних документів із метою створення національної нормативної бази, яка відповідає законодавству України і кращій світовій та, в тому числі, європейській практиці. Уніфікація законодавства у сфері стандартизації та сертифікації продукції сприятиме розвитку зовнішньої торгівлі, припливу іноземних інвестицій, 
Економічні науки: збірник наукових праць Луцького національного технічного університету. - Серія "Регіональна економіка". - Випуск 15 (59). - Редкол.: відп. ред. д.е.н., професор Л.Л. Ковальська. - Луцьк: ІВВ Луцького НТУ, 2018. - 292 с.

співробітництву у науково-технічній сфері. Хоча варто зазначити, що окрім посилення ролі міжнародних стандартів, Україна має запроваджувати і власні внутрішні стандарти, які призначені ретельно захищати інтереси національного споживача. Потрібно розуміти, що на даний момент законодавча база України не дозволяє повною мірою використовувати міжнародні норми і вимоги.

За визначенням Всесвітньої туристичної організації, якість - це виконання за встановленою і прийнятною ціною будь-яких бажань і сподівань клієнта, які не суперечать законодавству, при одночасному дотриманні вимог безпеки, гігієни і доступності туристичних послуг та гармонії людського і природного середовища [1].

Американський спеціаліст Дж. Харрінгтон, підходить до поняття якості наступним чином: якість - це «задоволення очікувань споживача за ціну, яку він може собі дозволити, коли в нього виникає потреба»; висока якість - це «перевищення очікувань споживача за більш низьку ціну, ніж він планує» [8].

У державному стандарті України наведено визначення якості продукції як економічної категорії, яка відображає сукупність властивостей продукції, що зумовлюють міру ii придатності задовольняти потреби споживача відповідно до свого призначення. Основні принципи та елементи систем якості, які охоплюють усі процеси, необхідні для забезпечення ефективності послуги, встановлює «ДСТУ 180 9004-2-96. Управління якістю та елементи системи якості. Частина 2. Настанови щодо послуг».

Якість послуги визначається вимогами ст. 6 Закону України «Про захист прав споживачів», згідно з яким виробник туристичної послуги зобов'язаний передати споживачеві продукцію, яка за якістю відповідає вимогам нормативних документів.

Заслуговує на увагу підхід до визначення поняття якості сформований професором Гарвардської школи бізнесу Д. Гарвіном, який розглядаючи поняття «якість», визначає п'ять найбільш істотних його характеристик (таблиця 1) [7]. 
Економічні науки: збірник наукових праць Луцького національного технічного університету. - Серія "Регіональна економіка". - Випуск 15 (59). - Редкол.: відп. ред. д.е.н., професор Л.Л. Ковальська. - Луцьк: ІВВ Луцького НТУ, 2018. - 292 с.

Таблиця 1

Основні підходи щодо розуміння якості

\begin{tabular}{|c|c|}
\hline Види підходів & Сутн \\
\hline $\begin{array}{l}\text { Трансцедентальний } \\
\text { погляд на якість }\end{array}$ & $\begin{array}{l}\text { Ототожнення поняття якості з поняттям } \\
\text { вихідної досконалості, стандартів і високих } \\
\text { досягнень, тобто відповідність технічним } \\
\text { показникам кращих аналогів }\end{array}$ \\
\hline $\begin{array}{l}\text { Підхід, який груунту- } \\
\text { ється на продукті }\end{array}$ & сонкпетною й вимірною змінною \\
\hline Виробничий I & $\begin{array}{lcc}\text { Ступінь точності } & \text { дотримання } & \text { усіх } \\
\text { виробничих процесів продукту } & \\
\end{array}$ \\
\hline $\begin{array}{l}3 \text { огляду на сподівання } \\
\text { споживачів }\end{array}$ & $\begin{array}{l}\text { Відповідність вимогам й очікуванням } \\
\text { споживачів }\end{array}$ \\
\hline $\begin{array}{l}\text { Підхід, базований } \\
\text { визначенні цінності }\end{array}$ & $\begin{array}{l}\text { Співвідношення цінності й ціни продукту } \\
\text { (відповідність платоспроможному попиту) }\end{array}$ \\
\hline
\end{tabular}

У практиці використовується термін система якості - що означає сукупність організаційної структури, методик, процесів і ресурсів, необхідних для здійснення загального керівництва якістю [6].

В туризмі дефініція якості складається 3 таких вимог: доступність, комунікабельність, компетентність, ввічливість, довірливість, стабільність і обережність, чуйність, безпека, чуттєвість та розуміння [2].

Оскільки вимоги до якості в туризмі визначає споживач, не може існувати такого поняття, як постійний рівень якості туристичних послуг. Підвищення якості повинне йти по зростаючій, тому що якість - це безперервно змінна ціль.

Якість надання туристичних послуг складається 3 таких структурних компонентів: соціальна - відповідність туристичних послуг рівню добробуту громадян, національним i регіональним традиціям та особливостям; етика; високой рівень культури; технічна - забезпечення належної матеріальнотехнічної бази, надання послуг за принципом комплексності та своєчасності; впровадження засобів автоматизації; правова відповідність туристичних послуг вимогам законодавчих актів, 
Економічні науки: збірник наукових праць Луцького національного технічного університету. - Серія "Регіональна економіка". - Випуск 15 (59). - Редкол.: відп. ред. д.е.н., професор Л.Л. Ковальська. - Луцьк: ІВВ Луичького НТУ, 2018. - 292 с.

стандартів, норм та правил, вивчення потреб та очікувань споживачів; економічна - туристична послуга повинна мати корисний ефект як для споживача (задовольняти його потреби, очікування), так і для сервісної організації (отримання прибутку).

Таким чином, виходячи 3 змісту якості туристичних послуг та їі складових можна визначити чинники, які впливають на досліджувану якість.

Одним 3 таких чинників $є$ інфраструктурне забезпечення туристичних регіонів держави. Так наприклад, на даному етапі стан транспортної системи України не можна вважати задовільним. Більшу частину інфраструктурних об'єктів транспорту необхідно визнати застарілими і такими, що не відповідають сучасним вимогам щодо виконання своїх основних функцій. Україна посіла 130-е з 137 місць у світовому рейтингу якості доріг, опинившись таким чином у ТОП-10 країн 3 найгіршими автотрасами. Хоча саме вони є першою ланкою туристичного потоку іноземних громадян в Україну.

Ще однією проблемою забезпечення якості туристичних послуг в регіонах є низький рівень обслуговування. Ввічливість i висока культура спілкування не потребують ніяких матеріальних затрат, додаткових витрат часу, саме ці чинники роблять атмосферу обслуговування максимально сприятливою. Отже, одним із головних завдань сучасного розвитку туристичної діяльності регіонів України $\epsilon$, постійне вдосконалення працівників, тому що саме вони мають найбільший вплив та значення на покращення процесу виробництва чи обслуговування. Чинне законодавство України містить нечіткість щодо визначення вимог готельного господарства. На сьогодні в Україні практично відсутня відповідна система в галузі туризму для підготовки i перепідготовки кадрів, а також чіткі та відповідні світовим стандартам кваліфікаційні вимоги.

Також, для підвищення рівня якості надання туристичних послуг необхідна ефективна система державних органів контролю. За останні 27 років відбулося 9 реорганізацій органу 
Економічні науки: збірник наукових праць Луцького національного технічного університету. - Серія "Регіональна економіка". - Випуск 15 (59). - Редкол.: відп. ред. д.е.н., професор Л.Л. Ковальська. - Луцьк: ІВВ Луичького НТУ, 2018. - 292 с.

виконавчої влади цієї галузі. Сьогодні центральним органом виконавчої влади в галузі туризму є Міністерство культури і туризму України.

Крім того, українське туристичне законодавство морально застаріло. Враховуючи вектор зовнішньої політики, доцільно використовувати туризм як майданчик для апробації європейських стандартів і принципів роботи. Необхідно привести норми Закону «Про туризм» у відповідність директивам $\mathrm{CC}$ в туристичній сфері, в першу чергу директиві СС від 13.06.1990 р. № 90/314 СС про комплексний туризм, відпочинок та тури. Закон повинен бути більш прикладним, а не декларативним, має містити основні вимоги та механізми реалізації послуг туристичними підприємствами.

За даними Всесвітньої туристичної організації ООН (UNWTO), за 2017 рік Україна заробила на туристах $\$ 1,261$ млрд. За підрахунками організації, Україну в 2017 році відвідали 14,23 млн туристів, що на 6,7\% більше, ніж у 2016 році.

Більшість регіонів регламентують підвищення якості туристичних послуг формуванням регіональних програм розвитку туризму[5]. Так наприклад, проблеми розвитку туризму в м. Львів розв'язувалися у межах Програми розвитку туризму на 2016-2022 роки, завдяки якій проведені основні заходи, що сприяли популяризації м. Львів як на українському, так і на міжнародному туристичних ринках. У 2017 році Львів прийняв 2,6 мільйона туристів, і хоча ця цифра у порівнянні 3 2016 роком залишилася практично незмінною, проте зросли такі важливі показники як середня тривалість перебування туриста у місті та його витрати. Витрати за день одного гостя в середньому склали 75 євро, що на 49 євро (30\%) більше, ніж у 2016 році. Відтак, цього року туристи залишили у два рази більше грошей у місті ніж у попередньому році, а саме, 615 млн. євро. В результаті прийому прес-туру для блогерів із США, було знято ролик про Україну та опубліковано 7 статей про Львів. Також, було проведено Дні європейської спадщини 2017, 
Економічні науки: збірник наукових праць Луцького національного технічного університету. - Серія "Регіональна економіка". - Випуск 15 (59). - Редкол.: відп. ред. д.е.н., професор Л.Л. Ковальська. - Луцьк: ІВВ Луиького НТУ, 2018. - 292 с.

Міжнародний день музеїв у Львові, Розумний маршрут «Вперше у Львові», Графіті-фестиваль «Алярм» [3].

До прикладу, на Волині також успішно реалізовуються регіональні програми розвитку туризму. Так, місто Луцьк згідно Програми розвитку туризму на 2017-2018 роки реалізувало значну кількість заходів туристичного спрямування, що дозволило підвищити якість туристичних послуг в регіоні.

Протягом 2017-2018 років Луцьк було представлено на 11 міжнародних туристичних виставках в Україні та за кордоном. У 2018 році створено новий промоційний відеоролик «Чому не варто їхати до Луцька», який за місяць переглянули більше ніж 100 тис. осіб. Вперше у 2018 році реалізовано проект фахової підготовки екскурсоводів для Луцька - Школа екскурсоводів. Двічі в 2017 та 2018 роках проведено Фестиваль «Стародавній Лучеськ. Доблесть віків». Створено місце для відпочинку на центральному пляжі в Парку культури i відпочинку ім. Лесі Українки «Креативна набережна». «Велоінфраструктура - ключ до розвитку туризму», в рамках якого встановлено 14 велопарковок. У 2018 році у Луцьку відбулися «Ніч у Луцькому замку», «Бандерштат» та інші фестивалі [9].

Висновки. Розвиток надання якісних туристичних послуг впливає на зайнятість населення, формування малого i середнього бізнесу, сприяє соціально-економічному розвитку регіонів, а саме транспортної, комунальної, інформаційної, виробничої та сервісної інфраструктури, роблять туризм важливою складовою частиною економічного i соціального розвитку.

1. Кудла Н.Є. Управління якістю в туризмі: підручник / Н. Кудла - К.: Центр учбової літератури, 2015. - 328 с.

2. Матвійчук Л.Ю. Раціоналізація використання та охорони туристичних ресурсів: діагностика та механізм забезпечення: Монографія / Людмила Матвійчук. - Луцьк: Волиньполіграф, 2011.- 340 с.

3. Офіційний веб-сайт Львівської міської ради [Електронний ресурс] Режим доступу: https://city-adm.lviv.ua/news/government/245703-departamentrozvytku-rozpoviv-pro-diialnist-ta-pro-rozvytok-turyzmu-u-2017-rotsi 
Економічні науки: збірник наукових праць Луцького національного технічного університету. - Серія "Регіональна економіка". - Випуск 15 (59). - Редкол.: відп. ред. д.е.н., професор Л.Л. Ковальська. - Луцьк: ІВВ Луичького НТУ, 2018. - 292 с.

4. Сагалакова Н.О. Характеристика туристичного продукту як специфічного об'єкта ціноутворення / Н.О. Сагалакова // Інвестиції: практика та досвід. - 2015. - №17. - С. 27-33.

5. Стратегія розвитку туризму та курортів на період до 2026 року / Розпорядження Кабінету Міністрів України від 16 березня 2017 р. № 168-р. [Ел. peсурс]. - Режим доступу : http://zakon2.rada.gov.ua/laws/show/168-2017-p.

6. Ткаченко T. Управление качеством гостинничных услуг / Т. Ткаченко // Гостинничный бизнес. - 2005. - № 4. - С. 24-27.

7. Харрингтон Дж. Совершенство управления процессами. - М.: Стандарты и качество, 2007. - $192 \mathrm{c.}$

8. Харрингтон Дж. Управление качеством в американских корпорациях / Дж. Харрингтон; пер. с англ. - М.: Экономика, 1990., с. 98

9. Офіційний веб-сайт Луцької міської ради [Електронний ресурс] Режим доступу: https://www.lutskrada.gov.ua/documents/pro-zvit-provykonannia-prohramy-rozvytku-turyzmu-u-misti-lutsku-na-2017-2018-rokyzatverdzhenoi-rishenniam-miskoi-rady-vid-30-11-2016-15-16 